RAFAŁ PILAREK

Uniwersytet Łódzki

Wydział Filozoficzno-Historyczny

Instytut Etnologii i Antropologii Kulturowej

\title{
ŚWIAT ROŚLIN W OBRZĘDOWOŚCI ŚWIĘTOJAŃSKIEJ NA PODSTAWIE ŹRÓDEŁ ETNOGRAFICZNYCH Z PRZELOMU XIX I XX WIEKU
}

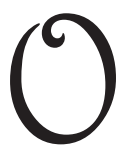
bchody świętojańskie należą do jednych z najstarszych i najbardziej archaicznych świąt dorocznych, charakteryzując się niezwykle bogatą obrzędowością, licznymi wierzeniami, wróżbami i praktykami magicznymi. Obchody te nawiązują do pradawnych świąt powitania lata, miłości i płodności, oczyszczających obrzędów ognia i wody oraz innych praktyk magicznych, których liczne relikty zachowały się do dziś w ludowych obchodach nocy świętojańskiej, zwanej m.in. sobótką, palinocka, nocq kupały, kupalnocka.

Przed pojawieniem się chrześcijaństwa w okresie przesilenia letniego, a więc w czasie wzmożonej aktywności sił natury, obrzędy ku czci słońca i płodności były praktykowane prawdopodobnie na terenie całej Europy. Kościół przez wieki zwalczał swobodne obyczaje, rozwiązłość młodzieży oraz wszystkie inne „diabelskie obchody”, jak je nazywali księża1. W ich miejsce duchowni starali się nakłonić wiernych do praktyk religijnych ku czci świętego Jana Chrzciciela, syna kapłana Zachariasza i Elżbiety krewnej Najświętszej Marii Panny. Kościół usiłował także łączyć niektóre zwyczaje i atrybuty ludowych obchodów świętojańskich z tradycją chrześcijańską. Pomimo tych starań pamięć o świętym Janie przetrwała jedynie w nazwach (noc świętojańska, ognie i deszcze świętojańskie, obchody świętojańskie itp.), praktykach święcenia ziół oraz w skojarzeniach wody, która

\footnotetext{
${ }^{1}$ B. Ogrodowska, Święta Polskie. Tradycja i obyczaj, Wydawnictwo Alfa, Warszawa 1996, s. 261.
} 
pełniła ważną rolę w zwyczajach ludowych jako chrześcijański symbol oczyszczenia i zbawienia.

Ta najkrótsza w roku noc była czasem odprawiania różnorakich czarów, wróżb, letnich uroczystości zadusznych, porą sprzyjającą magicznym praktykom miłosnym, czasem zgromadzeń i radosnych nocnych zabaw. Sądzono, że w okresie tym na ziemi przebywają duchy zmarłych, ufano, że za ich pośrednictwem i dzięki ich przychylności skuteczniejsze staną się odprawiane w tę noc czary. Wierzono, że jest to czas w którym wzrasta siła i aktywność demonów, a przede wszystkim czarownic, stosowano więc niezliczone środki przeciw ich urokom. Wśród ludu istniało przekonanie, że w noc świętojańską w ciała ludzi wstępują szczególne siły, że wzrasta ich gotowość do miłości, płodzenia i rodzenia. Stąd był to czas zalotów, wyznań miłosnych, kojarzenia młodych par i swobodnych zachowań seksualnych, na które zezwalały tradycja i obyczaj. Wierzono, że w tę szczególną noc zakwita paproć, której kwiaty przynoszą szczęście i skarby temu, kto je odnajdzie. Dla społeczności wiejskiej przełomu XIX i XX wieku był to czas pod każdym względem szczególny, cudowny i magiczny².

Rośliny w noc świętojańską nabierały - według wierzeń ludowych znanych we wszystkich regionach kraju - wyjątkowej mocy leczniczej, czarodziejskiej i erotycznej. Miały zatem szerokie zastosowanie w praktykach świętojańskich. Od zarania dziejów rośliny fascynowały ludzi nie tylko bogactwem form i barw, ale także niezwykłą zdolnością regeneracji i rozwoju. Stąd z roślinnością związane były w symbolice kultury ludowej idee nieskończonego, cyklicznie odradzającego się życia, zdrowia i płodności ${ }^{3}$. Ta niezwykła zdolność odradzania się roślin po zimowej pozornej śmierci stanowiła dla ludu wiejskiego odwieczną tajemnicę. Zjawiska te podobnie jak inne przypisywano siłom nadprzyrodzonym, które kierowały losem człowieka i wszystkim co go otacza. Rośliny nie należały zatem do „tego” świata, dlatego też „pojawiały się wszędzie tam, gdzie rytuały apelowały do zaświatów o przychylność, urodzaj i powodzenie".

2 Tejże, Zwyczaje, obrzędy i tradycje w Polsce, Wydawnictwo Verbinum, Warszawa 2001, s. $132-136$.

3 Z. Libera, A. Paluch, Lasowiacki zielnik, Biblioteka Publiczna Miasta i Gminy w Kolbuszowej, Kolbuszowa 1993, s. 104.

${ }^{4}$ A. Zadrożyńska, Świętowanie polskie. Przewodnik po tradycji, Wydawnictwo Książkowe „Twój Styl”, Warszawa 2002, s. 24, 26. 
W wieku XIX w dniu św. Jana chłopi po gruntownym oczyszczeniu zagrody „na całym froncie chałupy wtykali (w szczeliny) zielone gałązki z drzew i ziół" ${ }^{\prime \prime}$. Do przystrajania budynków mieszkalnych i gospodarskich używano najczęściej bylicy, łopianu, dziurawca, brzeziny, osiczyny, kobylaku, tataraku i piołunu. Zwyczaj ten występował na obszarze całej Polski, o czym świadczą bogate materiały etnograficzne i folklorystyczne zgromadzone przez Oskara Kolberga. Jedna z takich relacji pochodzi z Ziemi Kieleckiej:

(...) za strzechę zatykali różne zioła, jakoto: bylicę, łopienie, rumianek, tatarak, gałązki olszyny, wrotycz i inne, co się majeniem domu zowie. Zatykają najpierw bylicę, a zaraz potem łopiun, bzowy kwiat, bławatki i rutę

W podobny sposób dekorowano budynki mieszkalne na Mazowszu:

(...) dziewuchy rwały bylicę i łopian, i zioła te wtykali w izbie, lub tez w poszycie dachowe. (...) rzucali na dachy zabudowań łopian i bylicę, a we drzwiach mieszkania stawiali miotłę i to miało niedopuścić czarownic ${ }^{7}$.

Na Rusi Czerwonej do majenia domów i zagród używano wonnego ziela brezilu (bryzyliś), „które nad ranem nim słońce wzeszło zbierali i przy-

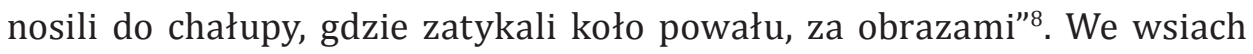
opoczyńskich dekorowano domostwa okazałymi bukietami z bławatków, łopianu, tataraku, pruszczyku, które gospodarze umieszczali w narożnikach izby. Wiązanki kwiatów układano także na kominach, na dachach, wciskano w szczeliny ścian i belek, budynków mieszkalnych i gospodarskich. Niekiedy wkładano ziele piołunu za węgły chałup, a z kwiatów i liści wito wieńce, którymi ozdabiano odrzwia chałup i obór. Lud nadrabski do dekorowania domostw na św. Jana wykorzystywał polne kwiaty: kąkole, bławatki, wykę i polny mak, które umieszczał „w równych odstępach i jednym rzędem w podstrzesza chałup" ${ }^{\prime \prime}$. Umieszczanie roślin pod strzechą domostw miało na celu ochronę domowników przed urokami złych

${ }^{5}$ 0. Kolberg, Dzieła wszystkie, Lubelskie, cz. I, t. 16, Ludowa Spółdzielnia Wydawnicza, Warszawa 1973, s. 119.

6 Tegoż, Kieleckie, cz. II, t. 19, s. 194.

7 Tegoż, Mazowsze Stare, t. 27, s. 135, 137.

8 Tegoż, Ruś Czerwona, t. 56, s. 226.

9 J. Świętek, Lud nadrabski od Gdowa po Bochni. Obraz etnograficzny, Kraków 1893, s. 114. 
ludzi, czarownicami i wszelkimi chorobami. Każda z roślin pełniła określoną funkcję ochronną: bylica miała zapobiegać kolkom i urazom, łopian i podbiał - wrzodom, kwiat bzu i lipy miał chronić przed kaszlem, a rumianek - przed gorączką ${ }^{10}$.

W dniu św. Jana mieszkańcy wielu wsi przyozdabiali roślinami przydrożne krzyże i figury świętych. Także ścieżki prowadzące do miejsc sakralnych były obstawione drzewkami lub gałązkami brzozy i jodły. Wierzono, że aromat i obecność roślin odpędzi złe siły, czary i uroki złych ludzi, a przede wszystkim uchroni przed czarownicami, szczególnie aktywnymi w okresie przesilenia letniego ${ }^{11}$. Aby zabezpieczyć się przed działaniem wiedźm, ścieżki wiodące do zabudowań gospodarskich i progi obór posypywano cierniem i kolcami róży ${ }^{12}$. Na Wileńszczyźnie kładziono pokrzywy na parapety i okna, aby „wiedźmy sobie oczy pokłuły”13. Rośliny miały także chronić ludzi przed piorunami, gdyż jak wierzono błyskawice polując na demony mogłyby spalić dom, gdyby diabelskie moce właśnie przebywały w izbie. Wielu ludzi miało ponieść śmierć dlatego, że „czarty ukrywały się za nimi"14.

Wśród roślin, którym tradycja ludowa przypisywała w dniu św. Jana szczególne właściwości magiczne i lecznicze była bylica ${ }^{15}$. Wzmianki o tej niepozornej roślinie pojawiły się w polskich zbiorach botanicznych dość wcześnie, bo już na przełomie XVI i XVII wieku. Wśród dzieł naukowych z tego okresu wyróżnia się Herbarz Marcina z Urzędowa z 1595 roku, w którym autor pisał: „zmęczeni drogą orzeźwiali się, gdy bylicą okładali nogi. Jest zielem czarodziejskim - odpędza czarownice od krów w stajni"16. Niezwykłe właściwości bylicy potwierdza Zielnik, autorstwa Szymona Syreńskiego z roku 1611. Ten wybitny botanik krakowski pisał, że bylica

10 O. Kolberg, Kieleckie, s. 194.

11 E. Frankowski, Kalendarz obrzędowy ludu polskiego, Warszawa 1929, s. 53.

12 B. Ogrodowska, Święta polskie..., s. 266.

13 K. Zawistowicz-Adamska, Obrzędowość świętojańska, „Wiedza i Życie” 1933, nr 7, s. 2.

14 E. Ferenc, Polskie tradycje świąteczne. Wydawnictwo Święty Wojciech, Poznań 2010, s. 170. Wierzono, że Święty Jan zawiadywał pogodą i deszczami oraz, że jest patronem w czasie burzy i gradobicia, opiekunem skazanych na śmierć, kowali i kupców. Za: B. Ogrodowska, Polskie obrzędy i zwyczaje doroczne, Wydawnictwo Sport i Turystyka - Muza SA, Warszawa 2005, s. 211.

15 Ł. Gołębiowski, Opisanie historyczno-statystyczne miasta Warszawy, Warszawa 1826, s. 227.

${ }_{16}$ Marcin z Urzędowa, Herbarz polski to jest o przyrodzeniu ziół i drzew rozmaitych, i innych rzeczy do lekarstw należących księgi dwoje..., Kraków 1595, s. 33. 
(...) zawieszona nad drzwiami, wrotami i oknami w wigilię św. Jana zachowuje domostwo przed najściem zła; W domu wieszana szataństwo z domu wypędza; Podczas burzy kadzenie bylicą zabezpiecza dom przed gromem $^{17}$.

Od wieków uczestnicy sobótek, zwłaszcza kobiety, przepasywały się bylicą - „pierwszym zielem świętojańskim”, której czarownice bały się bardziej niż ognia, i która w tę właśnie noc nabierała ogromnej mocy odwracania uroków, zarazy i wszelakiego zła. Wierzono, że bylica zaszyta w fałdach ubrania, noszona pod koszulą lub na gołym ciele chroniła przed bólami pleców i kości, młodym kobietom miała natomiast zapewnić płodność oraz szczęśliwy i lekki poród ${ }^{18}$. Roślina ta ze względu na swoje właściwości ochronne wykorzystywana była do uzdrawiania opętanych, stąd też bylicę „ucieczką czartowską nazywano”"19. Dla zapewnienia ochrony i zdrowia domowników umieszczano bylicę wewnątrz chałup. Świadczy o tym relacja z Kielecczyzny 0. Kolberga:

W wigilię św. Jana, mieszkańcy Secemin (pow. włoszczowski) zbierali bylicę i takową zatykali na czterech węgłach domu, oprócz tego i na drzwiach przy samem wnijściu do mieszkania. Służyć to miało na to, aby do tego domu i mieszkania przez cały rok nie wcisnęły się choroby ${ }^{20}$.

Wierzono, że skutecznym środkiem ochronnym przeciw czarom i urokom były wyplatane z bylicy płoty i drzwi ${ }^{21}$. W opoczyńskiem bylicą i łopianem ochraniano także wodę w studniach, w tym celu umieszczano na dnie studni świeże gałązki obu roślin ${ }^{22}$. Bylica ochraniała lud wiejski nie tylko przed czarownicami, złymi urokami czy chorobami, ale również przed piorunami. Potwierdza to relacja Władysława Siarkowskiego: „Dla ochronienia domu,

${ }^{17}$ S. Syreński, Zielnik. Herbarzem z języka Łacińskiego zowiq. To iest opisanie własne imion, kształtu, przyrodzenia, skutkow, y mocy Zioł wszelakich Drzew, Krzewów y korzenia..., Kraków 1610-1613, s. 725-726.

18 B. Ogrodowska, Święta..., s. 265. Władysław Siarkowski pisał: „Inni radzą opasać się bylicą tą, którą w wigiliją św. Jana Chrzciciela zakładają nade drzwiami domów i przez trzy dni chodzić tak przy rozpoczęciu żniw. W Pińczowskiem zaś w samą wigiliją świętego Jana zrywają bylicę i nią się opasują". Zob. W. Siarkowski, Materiały do etnografii polskiej z okolicy Kielc, Wydawnictwo „Takt”, Kielce 2000, s. 130.

${ }^{19}$ J. Dziarkowski, Wybór roślin krajowych dla okazana skutków lekarskich ku użytkowi domowemu, Warszawa 1806, s. 162-167.

20 O. Kolberg, Kieleckie, cz. I, t. 18, s. 51.

${ }^{21}$ Tegoż, Krakowskie, cz. II, t. 21, s. 63.

22 J. P. Dekowski, Zwyczaje i obrzędy sobótkowe w Opoczyńskiem, „Łódzkie Studia Etnograficzne", t. XXII, Łódź 1980, s. 113. 
stodoły, obory lub jakiegokolwiek budynku od pioruna, potrzeba w strzechę takiego zabudowania wetknąć bylicę"23.

Obok bylicy ważną rolę w obrzędowości świętojańskiej pełnił także dziurawiec, nazywany też niekiedy zielem świętojańskim lub dziurawkq. Roślina ta - jak wierzono - była szczególnie skuteczna w walce z czarownicami i demonami podmieniającymi dzieci. Uprzywilejowaną pozycję dziurawca tłumaczono szczególną cechą jego kwiatów, które po roztarciu wydzielały intensywnie czerwony sok, łudząco podobny do krwi ${ }^{24}$. W obchodach świętojańskich powszechnie wykorzystywany był także łopian. W podkrakowskich wsiach w celu ochrony domu i zwierząt przed złymi mocami umieszczano liście łopianu w narożnikach obór, pod strzechą, wkładano w szczeliny drzwi. Wyjęte z zamków podziurawione liście łopianu były znakiem wzmożonej aktywności wiedźm ${ }^{25}$.

W dniu św. Jana w wielu rejonach Polski wykonywano szereg zabiegów magicznych, których celem była ochrona upraw i zwierząt przed ingerencją złych mocy. W tym celu umieszczano w narożnikach pola części wianków dziewięciokrotnie święconych podczas oktawy Zielonych Świątek ${ }^{26}$. Na Pomorzu ochronę przeciw czarownicom stanowić miały ułożone na polu ścięte gałęzie drzew ${ }^{27}$, natomiast na Podlasiu funkcje ochronne pełniły wetknięte $\mathrm{w}$ ziemię gałązki osiki ${ }^{28}$. W dniu św. Jana szczególną troską otaczano rośliny głowiaste tj. kapustę, czosnek i cebulę ${ }^{29}$. Na Mazowszu chłopi licząc na dobre plony okopywali w tym dniu kapustę oraz zawiązy-

23 W. Siarkowski, Materiały..., s. 77.

24 E. Szot-Radziszewska, Sekrety ziół. Wiedza ludowa, magia, obrzędy lecznicze, Wydawnictwo Trio, Warszawa 2005, s. 182. Motyw pochodzenia czerwonych barw kwiatów lub liści $z$ krwią pojawił się w greckich mitach o Adonisie. Według legend pochodzenia niemieckiego, szkockiego i belgijskiego rdzawe plamy na liściach powstawały z kropel krwi Chrystusa. Czerwone zabarwienie młodych kiełków żyta legendy tłumaczyły tym, że powstało z krwi Abla. Ponadto w średniowieczu wierzono, że $z$ krwi poległych żołnierzy wyrastają kwiaty o czerwonych płatkach, na przykład goździki. Zob. J. Kołodziejczyk, Roślina w podaniach, legendach i symbolice, „Wiedza i Życie” 1946, z. 3, s. 202-203.

25 0. Kolberg, Krakowskie, cz. I, t. 5, s. 308.

26 J. P. Dekowski, dz. cyt., s. 115.

27 K. Kwaśniewicz, Zwyczaje i obrzędy rodzinne, [w:] Etnografia Polski. Przemiany kultury ludowej, t. II, pod red. M. Frankowskiej, M. Biernackiej, Wydawnictwo Naukowe PWN, Wrocław 1981, s. 146.

28 K. Zawistowicz-Adamska, dz. cyt., s. 2.

29 R. Hryń-Kuśmierek, Z. Śliwa, Encyklopedia tradycji polskich, Wydawnictwo Podsiedlik -Raniowski i S-ka, Warszawa 2000, s. 76. 
wali węzły na szczypiorze cebuli, aby cebule „lepiej się wiązały” i na czosnku, „zeby nie sed w ziemio”30.

W dniu św. Jana Chrzciciela chłopi poświęcali także wiele uwagi ochronie i opiece zwierząt hodowlanych. W okolicach Opoczna zaprzęgano w tym dniu po raz pierwszy młode woły do furmanek, co w przyszłości miało uchronić zwierzęta od bólów karku. Święcono w zagrodach krowy, konie, owce i drób. Zwyczaj święcenia zwierząt w dniu św. Jana nie dotyczył świń, uważanych przez chłopów za zwierzęta nieczyste ${ }^{31}$. Aby ustrzec się przed czarownicami, które odbierały zwierzętom „pożytki”, czyli mleko lub jaja ${ }^{32}$, przystrajano ziołami budynki inwentarskie, kadzono i święcono obory, podwórza i paśniki. O zabiegach ochronnych zwierząt w dniu św. Jana pisał O. Kolberg:

W wigilie świętego Jana wieśniaczki zatykają po oborach pokrzywę, zawieszają zielone wianki święcone (...) i zioła święcone przywiązują krowom do rogów, a to wszystko robią w przekonaniu, iż tym sposobem obronią krówki od napaści czarownicy $^{33}$.

Poza umieszczaniem na głowach zwierząt wianków z ziół niekiedy dodatkowo okadzano ziołami wymiona krów, aby „dobrze doiły”34. Poza powszechnie stosowaną bylicą i łopianem do ochrony inwentarza używano niekiedy lipy. W dniu św. Jana przed zmierzchem zatykano lipowe gałązki w strzechę nad drzwiami obory, „żeby mara nie wlazła i krowy nie wyssała” 35.

Miesiące maj i czerwiec były dla ludu wiejskiego czasem zbiorów ziół, przy tym w czerwcu obowiązywały pewne ograniczenia. W celu zachowania właściwości leczniczych roślin zalecano, aby zioła zbierać do dnia św. Jana Chrzciciela lub najpóźniej w samą wigilię święta, nigdy natomiast w samo święto lub tuż po nim. Tłumaczono to tym, że po św. Janie czarownice „opluwają” lub „zasmradzają” zioła tak, że tracą one swoje magiczne moce ${ }^{36}$.

${ }^{30}$ S. Dworakowski, Kultura społeczna ludu wiejskiego na Mazowszu nad Narwiq, Wydawnictwo Naukowe PWN, Białystok 1964, s. 110.

${ }^{31}$ J. P. Dekowski, $d z$. cyt., s. 114.

32 B. Baranowski, W kręgu upiorów i wilkołaków, Wydawnictwo Łódzkie, Łódź 1981, s. 223.

33 0. Kolberg, Białoruś - Polesie, t. 52, s. 124-125.

34 J. Dydowiczowa, Zwyczaje i obrzędy doroczne, [w:] Kultura ludowa Wielkopolski, t. III, pod red. J. Burszty, Wydawnictwo Poznańskie, Poznań 1967, s. 66.

${ }^{35}$ J. Smosarski, Świętowanie doroczne w Polsce, Wydawnictwo Więź, Warszawa 1996, s. 103.

${ }^{36}$ A. Paluch, Choroby, zioła, znachorzy, WA\&ZA, Namysłów 1991, s. 21. 
Do najczęściej zbieranych przez lud wiejski roślin na św. Jana należały: dziurawiec, dziewanna, piołun, rumianek, mięta, tysięcznik, szałwia i lubczyk ${ }^{37}$.

Tradycję zbierania ziół w tym okresie ilustruje jedna z relacji O. Kolberga z Wielkopolski:

W wigilię św. Jana Chrzciciela, po zachodzie słońca, udają się kobiety na bezdroża, łąki i pagórki, gdzie zbierają rozmaite zioła, np. czarcie żebro, odczynę, czyściec, laseczki pana Jezusa (...). Prócz tego zbierają gałązki olszowe, lipowe i zawieszają takowe nad drzwiami, a później, oberwawszy z nich listki, zasuszają je i przechowują do użycia na rozmaite rany ${ }^{38}$.

Dla dziewcząt na wydaniu specjalne znaczenie w noc świętojańską miał nasięźrzał. 0 miłosnych właściwościach tej rośliny pisał O. Kolberg: „Która dziewka dostanie tego ziela, ugotuje je i wywar wypije, będzie miała osobliwe szczęście do kawalerów (a nawet dosyć jest, aby jeno miała go przy sobie)”. To niepozorne ziele „zdobywało dziewczętom wzajemność serc, najbardziej nieczułych i obojętnych" ${ }^{39}$. Wierzono, że roślinę tę „sam diabeł strzeże, stąd, ażeby diabła oszukać, idzie się po nią tyłem, bo jakby tylko bies ujrzał, że ją ktokolwiek rwie i na nią patrzy, toby mu sam zaraz łeb urwał"40. Inne źródło podaje, że nasięźrzał należało rwać ręką założoną przez głowę, następnie szybko uciekać, nie oglądając się za siebie ${ }^{41}$. Na Podhalu, Kielecczyźnie, Pokuciu i Huculszczyźnie zioła zebrane w wigilię św. Jana Chrzciciela były także święcone, co dodatkowo zwiększało ich moce ochronne i leczni$\mathrm{cze}^{42}$. W wielu wsiach, zlokalizowanych w sąsiedztwie lasów dzień św. Jana rozpoczynano od zbierania jagód, zgodnie z przekonaniem, że: „na świnty Jan jagód dzban"³.

Czas przesilenia letniego, jak każdy okres graniczny, niósł za sobą niebezpieczeństwo kontaktu z hybrydyczną sferą istot mieszanych lub nawet z obcym porządkiem sacrum ${ }^{44}$. Stąd w kulturach tradycyjnych obowiązywał

${ }^{37}$ J. P. Dekowski, $d z$. cyt., s. 115. Szczególne znaczenie w tym okresie miał dziurawiec, chroniący rzekomo przed napaścią demonów napastujących głównie położnice i małe dzieci. Por. J. S. Bystroń, Etnografia Polski, Spółdzielnia Wydawnicza „Czytelnik”, Poznań 1947, s. 151.

38 O. Kolberg, Poznańskie, cz. I, t. 9, s. 143.

39 Tegoż, Kieleckie, cz. II, t. 19, s. 200.

${ }^{40}$ Tegoż, Krakowskie, cz. III, t. 7, s. 126.

${ }^{41}$ E. Ferenc, Polskie tradycje świąteczne, Wydawnictwo Święty Wojciech, Poznań 2010, s. 168.

42 A. Paluch, Zerwij ziele z dziewięciu miedz. Ziołolecznictwo ludowe w Polsce w XIX i początku XX wieku, Polskie Towarzystwo Ludoznawcze, Warszawa-Wrocław 1989, s. 32-33.

${ }^{43}$ J. P. Dekowski, dz. cyt., s. 115.

${ }^{44}$ P. Kowalski, Kultura magiczna. Omen, przesąd, znaczenie, Wydawnictwo Naukowe PWN, Warszawa 2007, s. 153. 
nakaz stosowania środków ochronnych, do których zaliczały się rośliny. Uważano, że był to czas, w którym mogły mieć miejsce niecodzienne zjawiska, stąd przekonanie, że pędy bez korzeni zasadzone w wigilię św. Jana przyjmują się i wyrastają z nich drzewa ${ }^{45}$. Czas przesilenia letniego sprzyjał także poszukiwaniu roślin, które mogły służyć człowiekowi z pożytkiem, przynieść mu szczęście i fortunę, tak jak legendarny kwiat paproci.

Punktem kulminacyjnym całego kompleksu zwyczajów świętojańskich było palenie ogni obrzędowych zwanych sobótkami, albo palinockami. Wokół sobótek tańczyły dziewczęta w wiankach na głowie. Niekiedy zamiast wianków kobiety wplatały we włosy lub układały przy chustach rutę, różę, nasturcję i nagietek. Jan Kochanowski zachwycony ludowym zwyczajem świętojańskim poświęcił mu poemat Pieśń świętojańska o Sobótce, w którym pisał:

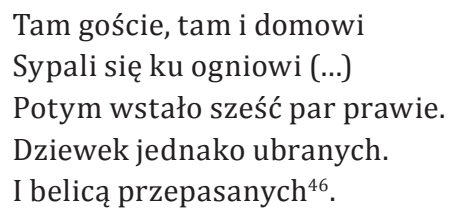

Nie tylko przychodzące na sobótki panny przepasywały się bylicą. Czyniły to także dojrzałe kobiety, niekiedy aż trzykrotnie, po to aby zapewnić sobie udane i szczęśliwe związki oraz ochronę przed czarami. Niekiedy miejsce zebrań odgradzano brzózkami, a w dni pochmurne stawiano namioty z zieleni ${ }^{47}$. Do palących się ognisk wrzucano przyniesione zioła: piołun, pokrzywę, konopię, bylicę i szałwię, wierzono bowiem, że w ten sposób przepędzone zostaną czarownice ${ }^{48}$. Bywało, że w ogniu płonęły także drzewka stawiane przed chałupami na Zielone Świątki oraz wiosenne maiki i mareny.

W obchodach świętojańskich ważną rolę spełniał mityczny kwiat paproci, który według legendy zakwitać miał o północy, przed świętym Janem. Wierzono, że kwiat świecił w nocy purpurowym, błękitnym lub złocistym blaskiem, a temu kto go „zobaczy i zerwie, wszystkie skarby ziemskie mu się otworzą"49, uzyska dar jasnowidzenia, a niekiedy i niewidzialności ${ }^{50}$.

\footnotetext{
${ }^{45}$ A. Paluch, Choroby..., s. 22-23.

${ }^{46}$ J. Kochanowski, Poezje, Wydawnictwo „Czytelnik”, Warszawa 1988, s. 186.

47 O. Kolberg, Białoruś - Polesie, t. 52, s. 66.

${ }^{48}$ K. Zawistowicz-Adamska, dz. cyt., s. 3.

49 O. Kolberg, Krakowskie, cz. III, t. 7, s. 123.

50 Tenże, Białoruś - Polesie, t. 52, s. 436.
} 
Odnaleźć go mógł jedynie człowiek odważny i prawy. Kwiatu należało szukać w „ustroni oddalonej, z dala od wioski i ludzi, ażeby nie dosłyszeć ani szczekania psów, ani dźwięków pieśni i muzyki, ani mowy, choćby szeptu człowieka"51. Śmiałkom szukającym mitycznego kwiatu miały ukazywać się przeróżne potwory zwierzęce, węże, żmije, ogromne ropuchy, przerażał ich nagły, gwałtowny wiatr i odgłosy rozlegające się zewsząd ${ }^{52}$. Według legend kwiat paproci rozkwitał na jedną tylko chwilę, a ponieważ strzegły go diabły i czarownice należało zerwać go przestrzegając zwyczajowych procedur ochronnych. Osoby szukające kwiatu powinny były zatem rozebrać się do naga, przepasać się na krzyż bylicą, różańcem lub szkaplerzem, trzymać w dłoniach Pismo Święte lub modlitewnik, a gdy udało się odnaleźć kwiat, kreślić wokół niego krąg kredą poświęconą w Trzech Króli ${ }^{53}$. Po wypełnieniu tych zaleceń należało

(...) leżeć cicho bez poruszenia. O godzinie północnej kur zapieje, ustają harce diabłów, a wtedy potrzeba szukać na całym sobie opadłego kwiatu z paproci, i gdy się go znajdzie schować w szkaplerz $(. . .)^{54}$.

Inna wersja tego wątku mówiła, iż należało

(...) zakreślić na ziemi koło, postawić naczynie z wodą święconą, świecę zapaloną i książkę do nabożeństwa; pod paprocią trzeba rozesłać chustkę jedwabną, i modląc się na klęczkach, oczekiwać chwili, w której kwiatek się pokaże i jaśniejąc silnym blaskiem, w postaci perły lub małej błyszczącej gwiazdki, spadnie na chustkę ${ }^{55}$.

W niektórych rejonach kraju wierzono, że kwiat paproci można było zachować i korzystać z jego dobroczynnej mocy, jeśli niezwłocznie po zerwaniu ukryło się jego płatek w ustach, pod językiem lub w ranie wcześniej naciętej na dłoni ${ }^{56}$. Nie zawsze jednak wyprawa po kwiat paproci wiązała się z ryzykiem i niebezpieczeństwami. Jedna z relacji 0. Kolberga z okolic Zamościa świadczy o czymś zgoła przeciwnym:

51 Tegoż, Mazowsze, cz. VII, t. 28, s. 359.

52 D. Dworakowski, Kultura..., s. 116.

53 B. Ogrodowska, Zwyczaje..., s. 101.

54 O. Kolberg, Lubelskie, cz. II, t. 17, s. 152.

55 Poszukiwania, „Wisła”, t. VIII, 1894, s. 820.

56 A. Lebeda, Komentarze do Polskiego Atlasu Etnograficznego, [w:] Wiedza i wierzenia ludowe, pod red. Z. Kłodnickiego, t. VI, Polskie Towarzystwo Ludoznawcze, Wrocław-Cieszyn 2002, s. 118. Wierzono, że umieszczenie kwiatu w ranie palca umożliwiało otwieranie wszystkich zamków. 
(...) nie ma żadnych strachów przy zbieraniu kwiatu paproci; tylko się trzeba w niej na noc w wigilię św. Jana położyć, a sam kwiat o północy za cholewę wpadnie, i nosić go trzeba za cholewą wciąż, dopóki się człowiek nie wzbogaci ${ }^{57}$.

Szczęście i powodzenie przynosił nie tylko kwiat paproci, ale także liście rośliny. W tym celu dziewczęta, których dziewiczość nie była wątpliwa, zrywały w lasach liście paproci i umieszczały je pod strzechą chałupy ${ }^{58}$. W Józwowie w powiecie Lubelskim wierzono, że w dniu św. Jana niezwykłe właściwości posiadał nie tylko kwiat paproci, ale także kwiat konopiany ${ }^{59}$. Na Kielecczyźnie szczególną rolę w tych dniach odgrywała świątniczka. Podobnie jak kwiat paproci roślina ta

(...) wszelkie odkrywała skarby. Także i świątniczki nikt nie widział. Chcąc ją dostać, trzeba narwać zielska przeróżnego, choćby cały wóz i następnie po jednej łodydze puszczać na wodę, a te które z tych ziół będzie pływać nie z wodą, lecz pod wodę, będzie właśnie szukaną świątnicką ${ }^{60}$.

Najważniejszym obrzędem dziewczęcym, który zachował się do naszych czasów, był zwyczaj puszczania wianków na wodę. Jak pisał Zygmunt Gloger:

(...) wieniec w prastarych pojęciach narodu polskiego był zawsze szczytnem godłem dziewictwa. Stąd oddanie wieńca młodzieńcowi przez dziewicę, jest symbolem oddania mu serca i ręki, symbolem zamążpójścia ${ }^{61}$.

Kobiety na wydaniu ${ }^{62}$ oraz młode wdowy ${ }^{63}$ wiły więc wianki z kwiatów polnych i ogrodowych, z barwinku, bylicy, rozchodnika, kołowrotka, rumianku, mirtu, geranium, nawrotka, dziurawca, mięty oraz lnu, wykradzionego z pola należącego do rodziny mającej samych synów, potencjalnych kandydatów na męża. Do najważniejszych roślin miłosnych, sprzyjających zamążpójściu, należały jednak ruta, macierzanka i lubczyk ${ }^{64}$. 0 tej ostatniej pisał O. Kolberg: „Cudowniejszem może zielem jest Lubystek czyli Lubczyk

57 O. Kolberg, Lubelskie, cz. II, t.17, s.152; Krakowskie, cz. III, t. 7, s.124.

58 Gródek Nadbóżny, „Wisła”, t. IX, 1895, s. 131.

${ }^{59}$ Kwiat paproci i kwiat konopiany, „Wisła”, t. VIII, 1894, s. 819.

${ }^{60}$ O. Kolberg, Krakowskie, cz. III, t. 7, s. 123.

61 Z. Gloger, Rok polski w życiu, tradycyi i pieśni, Warszawa 1900, s. 287.

${ }^{62}$ W Opoczyńskiem puszczaniem wianków zajmowały się dziewczęta od lat dwunastu do zamążpójścia. Zob. J. P. Dekowski, dz. cyt., s. 109.

${ }^{63}$ Ł. Gołębiowski, Gry i zabawy różnych stanów w kraju całym, lub niektórych tylko prowincyach, Warszawa 1831, s. 294, 297.

64 J. P. Dekowski, dz. cyt., s. 109. 
(Sigisticum officin), w którym matki kąpią córki, żeby dorósłszy, chłopakom się podobały"65. Obowiązywał zakaz zrywania roślin z terenów otwartych, przez które przetaczały się kondukty pogrzebowe. Zioła zerwane w tych miejscach miały mieć fatalny wpływ na ustalanie horoskopów matrymonialnych, a co gorsze przynosić pewne nieszczęście ${ }^{66}$. Uwite wianuszki były okrągłe i najczęściej niewielkich rozmiarów (średnica wianków dochodziła do $8 \mathrm{~cm}$ ). Po upleceniu przywiązywano je lnianą nitką do cienkich deseczek, pośrodku których umieszczano świeczki ${ }^{67}$. Ilustruje to opis sporządzony przez O. Kolberga:

(...) wianki te z różnych spleciono kwiatów, przytwierdzone są do kółka z cieniutkiej deszczki, również w kształcie wieńca, wykrojonego, różnej wielkości. Drzewo to służy do podtrzymywania świeczek albo lamp, czasami różnokolorowych ${ }^{68}$.

Niekiedy do wianuszków przywiązywano kartki z wdzięcznymi wierszykami typu: „płyń wianeczku a nie wróć, me ciężkie cierpienie skróć. A ty Józio chwyć go schwyć, byś mym mężem mógł już być”69. Zawsze jednak do deseczki dołączony był podpis, do której dziewczyny wianek należy ${ }^{70}$. Z obserwacji przemieszczających się wianków dziewczęta wyciągały dla siebie horoskopy matrymonialne. Pisze o nich O. Kolberg:

Ta z dziewcząt, której wianek nieschwytany popłynął w dal ze światłem, jeśli go dojrzała, wie już że nie pójdzie tego roku za mąż; ta której wianek przypadkiem w nurtach zatonął i świecić przestał lub dla przeszkód drogę swą zwichnął - straci go lub zamrze; ta jedynie której wieniec przez zręcznych schwytany został rabusiów, znajdzie w tym jeszcze roku męża i opiekuna ${ }^{71}$. Jeżeli wieniec kręci się długo w kółko, to dziewka jeszcze nie prędko pójdzie za mąż; a jeżeli wieniec pójdzie od razu za wodą, to jeszcze tego roku czeka ją zamęźcie ${ }^{72}$.

W Opoczyńskiem przyjęty był zwyczaj, iż chłopiec, który chwycił płynący wianek, stawał się narzeczonym właścicielki wianka. Zawsze wiele smutku wywoływały zgasłe świeczki, gdyż były symbolem nieszczęścia i bolesnych

${ }^{65}$ 0. Kolberg, Kieleckie, cz. II, t. 19, s. 200.

${ }^{66}$ J. P. Dekowski, dz. cyt, s. 110.

67 O. Kolberg, Krakowskie, cz. I, t. 5, s. 308.

68 Tamże, s. 309.

69 Tegoż, Mazowsze, cz. I, t. 24, s. 172.

${ }^{70}$ F. Kotula, Przeciw urokom, Ludowa Spółdzielnia Wydawnicza, Warszawa 1989, s. 148.

71 O. Kolberg, Mazowsze, cz. I, t. 24, s. 169.

72 Tegoż, Krakowskie, cz. I, t. 5, s. 309. 
rozczarowań. W niektórych wsiach opoczyńskich dziewczęta po uroczystościach sobótkowych zabierały swoje wianki z wód stojących i zakopywały je w ogródku, najczęściej pod lilią lub rutą, zabezpieczając je w ten sposób przed poniewierką i czarami ${ }^{73}$. Zwyczaj puszczania wianków w dniu św. Jana był znany także mieszkańcom miast o czym świadczy relacja Łukasza Gołębiowskiego, autora jednej z pierwszych prac o historii Warszawy. Pisał on, że „w wigilię św. Jana dziewczęta puszczają wianki na bieżącą wodę z róż, bławatków i innych kwiatów uplecione, najwięcej ich bywa pomiędzy 8 a 9 godziną wieczorną"74. W wigilię św. Jana dziewczęta czyniły też wróżby poza wodą. W wielu regionach Polski wróżono sobie rzucając wianek trzykrotnie przez ramię na rosnące nieopodal drzewo $^{75}$. W opoczyńskiem dziewczyny rzucały wianki na lipę, i jeżeli się tam zatrzymały wróżyły, „ze pewnikiem tego jesce roku wejdum za chłopa"76. Niekiedy kobiety rzucały za siebie po dwa wianki, jeżeli upadły blisko siebie, zapowiadało to szybkie skojarzenie młodej pary. Zdarzało się niekiedy, iż oprócz małych wianków panny z całej wsi plotły jeden wielki od całej gromady i w noc św. Jana niosły go ze śpiewem nad rzekę, wspólnie puszczały na wodę, aby wszystkim stojącym na brzegu dziewczętom przyniósł powodzenie w miłości i udane, szczęśliwe małżeństwo. Ponadto wianuszek zawieszony na drzwiach chałupy stanowił czytelny znak, że mieszka w niej panna na wydaniu ${ }^{77}$.

Po świętojańskiej nocy wszystko powinno było wrócić do normy. Wprawdzie na Mazowszu gospodynie w św. Jana szły jeszcze do obór z zapalonymi gromnicami i każdej krowie do rogów przyczepiały wianki z ziół, ale wydaje się, że były to ostatnie już zabiegi zabezpieczające i ochronne ${ }^{78}$. I choć gdzieniegdzie widywano jeszcze rusałki, biegające wśród zbóż, to chłopi myśleli już o żniwach. Kończyły się święta, rośliny na powrót stawały się codziennym i zwyczajnym elementem wiejskiego krajobrazu.

${ }^{73}$ J. P. Dekowski, dz. cyt., s. 111.

74 Ł. Gołębiowski, Opisanie historyczno-statystyczne miasta Warszawy, Warszawa 1826, s. 227.

75 B. Ogrodowska, Zwyczaje..., s. 233.

${ }^{76}$ J. P. Dekowski, dz. cyt., s. 111.

77 B. Ogrodowska, Zwyczaje..., s. 233.

78 A. Zadrożyńska, Powtarzać czas początku. Cz. I, O świętowaniu dorocznych świq̨t w Polsce, Wydawnictwo Spółdzielcze, Warszawa 1985, s. 131. 


\section{BIBLIOGRAFIA}

- Baranowski B., W kręgu upiorów i wilkołaków, Wydawnictwo Łódzkie, Łódź 1981.

- Bystroń J. S., Etnografia Polski, Spółdzielnia Wydawnicza „Czytelnik”, Poznań 1947.

- Dekowski P., Zwyczaje i obrzędy sobótkowe w opoczyńskiem, „Łódzkie Studia Etnograficzne", t. XXII, Łódź 1980.

- Dworakowski S., Kultura społeczna ludu wiejskiego na Mazowszu nad Narwiq, Wydawnictwo Naukowe PWN, Białystok 1964.

- Dydowiczowa J., Zwyczaje i obrzędy doroczne, [w:] Kultura ludowa Wielkopolski, t. III, pod red. J. Burszty, Wydawnictwo Poznańskie, Poznań 1967.

- Dziarkowski J., Wybór roślin krajowych dla okazana skutków lekarskich ku użytkowi domowemu, Warszawa 1806.

- Ferenc E., Polskie tradycje świq̨teczne. Wydawnictwo Święty Wojciech, Poznań 2010.

- Frankowski E., Kalendarz obrzędowy ludu polskiego, Warszawa 1929.

- Gloger G., Rok polski w życiu, tradycyi i pieśni, Warszawa 1900.

- Gołębiowski Ł., Gry i zabawy różnych stanów w kraju całym, lub niektórych tylko prowincyach, Warszawa 1831.

- Gołębiowski Ł., Opisanie historyczno-statystyczne miasta Warszawy, Warszawa 1826.

- Gródek Nadbóżny, „Wisła”, t. IX, 1895.

- Hryń-Kuśmierek R., Śliwa Z., Encyklopedia tradycji polskich, Wydawnictwo Podsiedlik -Raniowski i S-ka, Warszawa 2000.

- Kochanowski J., Poezje, Wydawnictwo „Czytelnik”, Warszawa 1988.

- Kolberg 0., Dzieła wszystkie, Białoruś - Polesie, t. 52, Ludowa Spółdzielnia Wydawnicza, Warszawa 1973.

- Kolberg 0., Mazowsze, cz. I, t. 24.

- Kolberg 0., Mazowsze, cz. VII, t. 28.

- Kolberg O., Mazowsze Stare, t. 27.

- Kolberg O., Ruś Czerwona, t. 56.

- Kolberg O., Kieleckie, cz. I, t.18.

- Kolberg O., Kieleckie, cz. II, t.19.

- Kolberg 0., Krakowskie, cz. I, t. 5.

- Kolberg O., Krakowskie, cz. II, t. 21.

- Kolberg O., Krakowskie, cz. III, t. 7.

- Kolberg O., Kieleckie, cz. II, t. 19.

- Kolberg O., Lubelskie, cz. I, t. 16.

- Kolberg 0., Lubelskie, cz. II, t. 17. 
- Kolberg O., Poznańskie, cz. I, t. 9.

- Kołodziejczyk J., Roślina w podaniach, legendach i symbolice, „Wiedza i Życie” 1946, z. 3.

- Kotula F., Przeciw urokom, Ludowa Spółdzielnia Wydawnicza, Warszawa 1989.

- Kowalski P., Kultura magiczna. Omen, przesq̨d, znaczenie, Wydawnictwo Naukowe PWN, Warszawa 2007.

- Kwaśniewicz K., Zwyczaje i obrzędy rodzinne [w:] Etnografia Polski. Przemiany kultury ludowej, t. II, pod red. M. Frankowskiej, M. Biernackiej, Wydawnictwo Naukowe PWN, Wrocław 1981.

- Kwiat paproci i kwiat konopiany, „Wisła” t. VIII, 1894.

- Lebeda A., Komentarze do Polskiego Atlasu Etnograficznego [w:] Wiedza i wierzenia ludowe, pod red. Z. Kłodnickiego, t. VI, Polskie Towarzystwo Ludoznawcze, Wrocław -Cieszyn 2002.

- Libera Z., Paluch A., Lasowiacki zielnik, Biblioteka Publiczna Miasta i Gminy w Kolbuszowej, Kolbuszowa 1993.

- Marcin z Urzędowa, Herbarz polski to jest o przyrodzeniu ziół i drzew rozmaitych, i innych rzeczy do lekarstw należących księgi dwoje..., Kraków 1595.

- Ogrodowska B., Święta Polskie. Tradycja i obyczaj, Wydawnictwo Alfa, Warszawa 1996.

- Ogrodowska B., Zwyczaje, obrzędy i tradycje w Polsce, Wydawnictwo Verbinum, Warszawa 2001.

- Ogrodowska B., Polskie obrzędy i zwyczaje doroczne, Wydawnictwo Sport i Turystyka - Muza SA, Warszawa 2005.

- Paluch A., Zerwij ziele z dziewięciu miedz: ziołolecznictwo ludowe w Polsce $w$ XIX i początku XX wieku, Polskie Towarzystwo Ludoznawcze, Warszawa-Wrocław 1989.

- Paluch A., Choroby, zioła, znachorzy. WA\&ZA. Namysłów 1991.

- Poszukiwania, „Wisła”, t.VIII, 1894.

- Siarkowski W., Materiały do etnografii polskiej z okolicy Kielc, Wydawnictwo „Takt”, Kielce 2000.

- Smolarski J., Świętowanie doroczne w Polsce, Wydawnictwo Więź, Warszawa 1996.

- Syreński S., Zielnik. Herbarzem z języka Łacińskiego zowiq̨. To iest opisanie własne imion, kształtu, przyrodzenia, skutkow, y mocy Zioł wszelakich Drzew, Krzewów y korzenia..., Kraków 1610-1613.

- Świętek J., Lud nadrabski od Gdowa po Bochni. Obraz etnograficzny, Kraków 1893.

- Szot-Radziszewska E., Sekrety ziót. Wiedza ludowa, magia, obrzędy lecznicze, Wydawnictwo Trio, Warszawa 2005.

- Zadrożyńska A., Powtarzać czas początku. Cz. I, O świętowaniu dorocznych świąt w Polsce, Wydawnictwo Spółdzielcze, Warszawa 1985.

- Zadrożyńska A., Świętowanie polskie. Przewodnik po tradycji, Wydawnictwo Książkowe „Twój Styl”, Warszawa 2002.

- Zawistowicz-Adamska K., Obrzędowość świętojańska, „Wiedza i Życie” 1933, nr 7. 


\section{THE WORLD OF PLANTS IN ST. JOHN RITUALS. ETHNOGRAPHIC SOURCES FROM THE LATE NINETEENTH AND EARLY TWENTIETH CENTURIES}

The celebration of Midsummer's Eve is one of oldest and the most archaic celebrations characterized by unusually rich rituals, numerous beliefs, divination and magic practices. These celebrations took place during the summer solstice which by its particular timing were threatening contacts with the alien order of sacrum. Because of this, protective measures were mandatory in traditional cultures. During the Midsummer Night, according to people's beliefs in all areas of Poland, plants were developing remedial, fairy and erotic forces. Therefore, they were widely used in miscellaneous practices about which we can learn from a variety of ethnographic materials from the $19^{\text {th }}$ and the $20^{\text {th }}$ century.

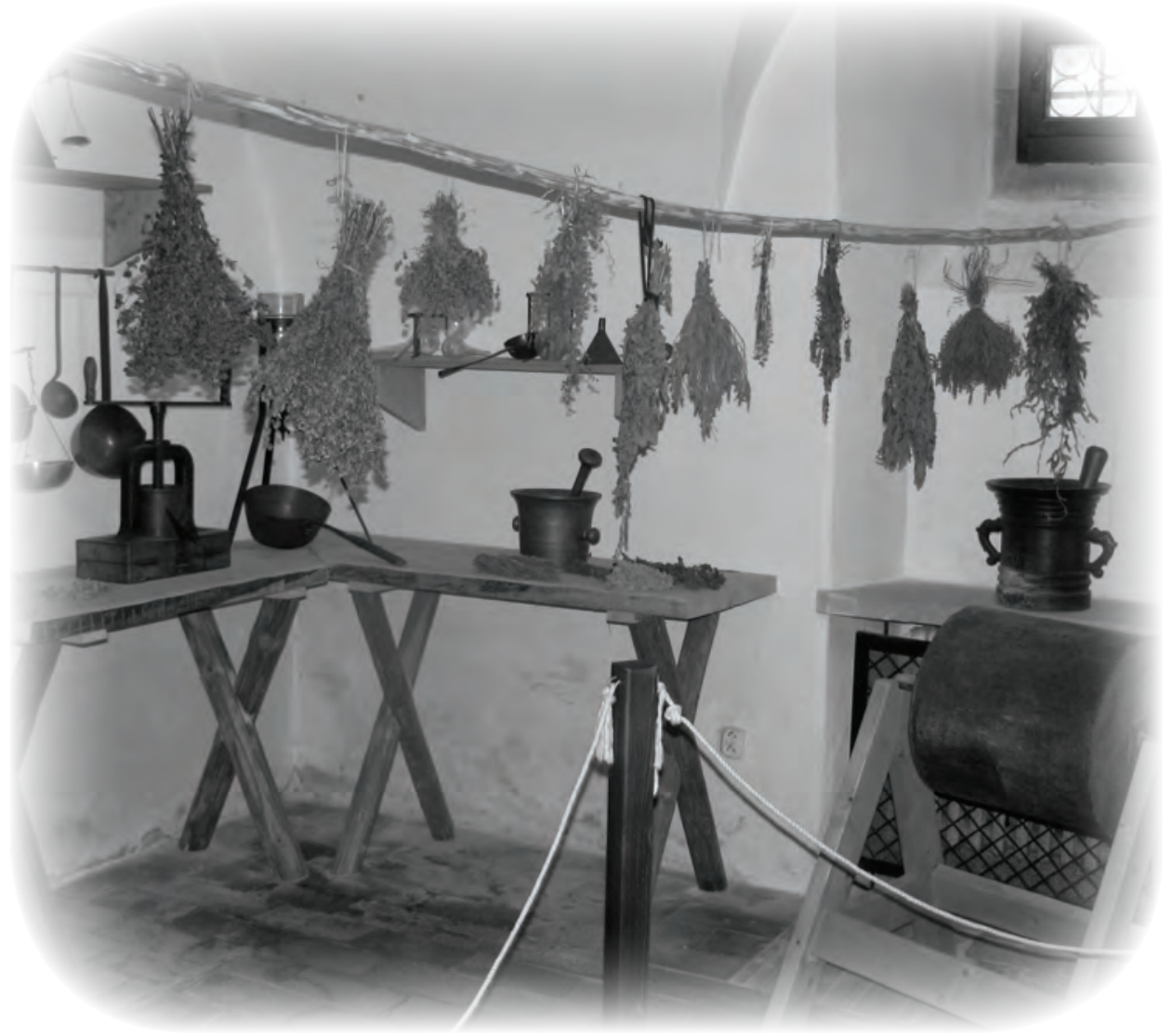

